CURRENT BIBL IOGRAPHY

Recently published works pertaining to sedimentary geology in the Maritime region and environs are 1 isted below. They have been extracted from Geoscience Abstracts for July, August, September, and October 1966.

Geological Maps and Regional Geology

ANDERSON, F.D., 1965, Geology, Belleoram, Newfound1and: Canada, Geo1. Survey, Map 8-1965.

CHANG, PING HSI, et a1, 1965, Bedrock geology of the Woodstock Quadrangte, Vermont: Vermont, Geol. Survey, Bu11. No. 20, 65 p.

INTERNATIONAL ASSOCIATION FOR QUATERNARY RESEARCH, 7TH CONGRESS, BOULDER, COLORADO, 1965, Guidebook for Field Conference A: New England New York State: Ed C. BERTRAND SCHULTZ and H.T.U. SMITH: Lincoln, Nebraska Academy of Sciences, $92 \cdot \mathrm{p}$.

ST-JULIEN, PIERRE, and R.-Y. LAMARCHE, 1965, Geology of Sherbrooke area, Sherbrooke County: Québec, Dept. of Nat. Resources, Prelim. Rept. No. $530,34 \mathrm{p}$.

\title{
Geomorphology
}

ANDREWS, J.T., and B.B. SMITHSON, 1966, Till fabrics of the cross-valley moraines of north-central Baffin Island, Northwest Territories, Canada: Geol. Soc. America, Bu11., v. 77, no. 3, p. 271-290.

CAMU, PIERRE, et al, 1965, Economic geography of Canada, with an introduction to a 68-region system: 393 p., New York, St. Martin's Press.

DOLAN, ROBERT, and JAMES MCCLOY, comps., 1965, Selected bibliography on beach features and related nearshore processes: Louisiana State Univ. Studies, Coastal Studies Ser。, no. $11,59 \mathrm{p}$.

HARRISON, D.A., 1966, Recent fluctuations of the snout of a glacier at McBeth Fiord, Baffin Island, N.W.T.: Geog. Bull, v. 8, no. 1, p. 48-58.

PETERSON, JAMES A., 1965, Deglaciation of the Whitegull Lake area, Labrador-Ungava: Cahiers de Geographie de Québec, v. 9, no. 18, p. 183-195.

PETERSON, JAMES A。, 1965, Ice-push ramparts in the George River Basin, Labrador-Ungava: Arctic, v. 18, no. 3, p. 189-193.

RVACHEV, V.D., 1965, Topographic relief and bottom sediments of the Georges and Banquereau Banks. Translated by E.R. HOPE: Canada, Directorate Sci. Inf. Service, Defence Research Board, Translations T436R, 7 p.; Materialy Rybokhoziaistvennykh Issledovanii Severnogo Basseina, 1964, no. 2.

SAGAR, R.B., 1966, Glaciological and climatological studies on the Barnes Ice Cap. 1962-64: Geog. Bu11., v. 8, no. 1, p. 3-47.

THORNES, JOHN, 1965, Some Observations on the late-glacial stages in the Coaticook Valley, southern Québec: Cahiers de Geographie de Québec, v. 9 ; no. 18 , p. 223-238.

UCHUPI, ELAZAR, 1.966, Topography and structure of Northeast Channe1, Gu1f of Maine: Am. Assoc. Petroleum Geologists, Bu11., v. 50, no. 1, p. 165-167.

MAHER, JOHN C., 1965, Correlations of subsurface Mesozoic and Cenozoic rocks along the Atlantic Coast: Tulsa, Oklahoma, American Assofiation of Petroleum Geologists, 18 p. 
Paleontology

BARTLETT, G.A., 1966, Foraminifera distribution in Tracadie Bay, Prince Edward Island: Canada, Geol. Survey, Paper 66-20, 54 p.

BELL, W.A., 1966, Illustrations of Canadian fossils: Carboniferous plants of Eastern Canada: Canada, Geo1. Survey, Paper 66-11, 76 p.

BOLTON, THOMAS E., 1966, Catalogue of type invertebrate fossils of the Geological Survey of Canada: Volume III: 203 p., Ottawa, Geological Survey of Canada.

MOORE, RAYMOND C., ed., 1965, Treatise on invertebrate Paleontology. Part H. Brachiopoda, by Alwyn Williams et al: New York and Lawrence, Kansas, Geological Society of America and University of Kansas Press, 2 v., 927 p.

SCHOPF, THOMAS J.M., 1966, Conodonts of the Trenton Group (Ordovician) in New York, Southern Ontario, and Québec: New York, State Mus. \& Sci. Service, Bu11, No. 405, 105 p.

SHAW, ALAN B。, 1966, Paleontology of northwestern Vermont. XI. Fossils from the Middle Cambrian St. Albans Shale: Jour. Paleontology, v. 40, no. 4, p. 843-858.

\section{Structural Geology}

BOYLE, R.W., 1964, Folds in the Carboniferous rocks near Walton, Nova Scotia: Am. Jour. Sci., v. 262, no. 10, p. 1233-1234.

FYSON, W.K., 1964, reply to above: 1oc. cit., p. 1234.

KING, PHILIP B., 1964, Further thoughts on tectonic framework of southeastern United States: Virginia Polytech. Inst., Dept. Geol. Sci., Mem. 1, $31 \mathrm{p}$.

LILLY, H.D., 1966, Late Precambrian and Appalachian tectonics in the light of submarine exploration on the Great Bank of Newfoundland and in the Gulf of St. Lawrence. Preliminary Views: Am. Jour. Sci., v. 264, no. 7, p. 569-574.

PIERCE, KENNETH L., and RICHARD L. ARMSTRONG, 1966, Tuscarora Fault, an Acadian (?) bedding-plane fault in central Appalachian Valley and Ridge Province: Am. Assoc. Petroleum Geologists, Bul1., v. 50, no. 2, p. 385-390.

UCHUPI, ELAZAR, 1966, Structural framework of the Gulf of Maine: Jour. Geophys. Research, v. 71, no. 12, p. 3013-3028.

Geophysics

COMPTON, P.A., 1964, Recent changes of sea-level along the northeast coast of Brodeur Peninsula, Baffin Island, N.W.T., Canada: Arctic, V. 17, nó. 4, p. 279-285.

HALES, ANTON L., et a1, 1966, Some logistics of the East Coast on-shore offshore experiment (ECOOE): Seismo1. Soc. America, Eastern Sec., Earthquake Notes v. 37, no. 1, p. 25-32.

LATHAM, GARY V。, and GEORGE H. SUTTON, 1966, Seismic Measurements on the Ocean Floor. 1. Bermuda Area: Jour. Geophys. Research, v. 71, no. 10. p. 2545-2573. 
LONCAREVIC, B.D., et al, 1966, Mid-Atlantic Ridge near $45^{\circ}$ North. I. The median valley: Can. Jour. Earth Sci., v. 3, no. 3, p. 327-349.

McGERRIGLE, H.W., 1966, Earthquakes and the Province of Quebec: Can. Mining \& Metal Bul1., v. 59, no. 649, p. 637-640.

OPYDKE, N.D., and H. WENSINK, 1966, Paleomagnetism of rocks from the White Mountain Plutonic-Volcanic Series in New Hampshire and Vermont: Jour. Geophys. Research, v. 71, no. 12, p. 3045-3051.

\section{Sedimentary Petrology}

MURRAY, D.A., 1966, Limestones and dolomites of Cape Breton Island: Can. Mining \& Metal1. Bu11., v. 59, no. 649, p. 626-629.

OTVOS, ERVIN G., JR., 1966, Sedimentary structures and depositional environments, Potsdam Formation, Upper Cambrian: Am. Assoc. Petroleum Geologists, Bull., v. 50, no. 1 , p. 159-165.

\section{Fuels and Mineral Deposits}

HOWIE, R.D., 1966, Catalogue of well samples from Nova Scotia, New Brunswick, Prince Edward Island and Newfoundland at the Geological Survey of Canada, Ottawa: ... Canada, Geol. Survey, Paper 65-40, 43 p.

MILNE, J.E.S., and R.D. HOWIE, 1966, Developments in Eastern Canada in 1965: Am. Assoc. Petroleum Geologists, Bull., v. 50, no. 6, p. 1295-1310.

MULLIGAN, ROBERT, 1966, Geology of Canadian tin occurrences: Canada, Geol. Survey, Paper 64-54, 22 p.

PRESANT, E.W., and W.M. TUPPER, 1966, The distribution and nature of arsenic in the soils of the Bathurst, New Brunswick, district: Econ. Geology, v. 61, no. 4, p. 760-767.

RICHARDS, HORACE G., and others, 1966, 0i1 and gas developments in Northeastern States in 1965: Am. Assoc. Petroleum Geologists, Bul1., v. 50 , no. 6 , p. 1139-1161.

SPROULE, J.C., and REIN DE WIT, 1964, Evolution of Arctic Islands exploration methods: Can. Inst. Mining \& Meta11., Trans., v. 67, p. 277-281.

\section{Miscel1aneous}

CANADA, DEPT. OF MINES AND TECHNICAL SURVEYS, 1965, Annual report calendar year 1964: $54 \mathrm{p}$. 